\title{
In vitro antibacterial activity and potential applications in food of sea urchin (Diadema setosum) from Cape of Palette, South Sulawesi
}

\author{
1,* Yusuf, M., ${ }^{2}$ Fitriani Nur, U.A. and ${ }^{1}$ Rifai, A. \\ ${ }^{1}$ Department of Chemical Engineering, Politeknik Negeri Ujung Pandang, Jl. Perintis Kemerdekaan KM. 10 \\ Tamalanrea, 90245, Makassar City, Indonesia \\ ${ }^{2}$ Department of Agroindustry, Politeknik Pertanian Negeri Pangkep, Jl. Poros Makassar - Parepare KM. 83 \\ Mandalle, 90655, Pangkep Regency, Indonesia
}

\begin{abstract}
Article history:
Received: 10 June 2020

Received in revised form: 5 July 2020

Accepted: 16 July 2020

Available Online: 7

September 2020

Keywords:

Antibacterial activity,

Diadema setosum,

Disc diffusion method,

Sea urchin
\end{abstract}

DOI:

https://doi.org/10.26656/fr.2017.4(6).275

\begin{abstract}
Marine invertebrates in support of his life's defence of sea predatory use an innate immune mechanism, namely the cellular component hemocytes by secreting the dissolved antimicrobial and cytotoxic substances. It shows that marine invertebrates are potential sources and promising antimicrobial compounds. This research was aimed at determining the antibacterial activity of sea urchin (Diadema setosum) extract against some bacterial isolates and its application to foodstuffs. The gonad and shell of sea urchin extracted by methanol and ethyl acetate and then separated by ultrasound-assisted extraction. Screening of antibacterial compound use gas chromatography-mass spectrometry (GC-MS), and disc diffusion method was followed to determine the antimicrobial activity against Salmonella, Escherichia coli and Staphylococcus aureus. The results of this study showed antibacterial activity against one or more strains. The gonad of sea urchin from methanol extract exhibited significant inhibitory effect and effective against Salmonella, E. coli and $S$. aureus. Majority of gonad and shell of sea urchin extract showed antibacterial activity against the tested strains. However, gonad of methanol extract was found to be inhibiting microorganisms gram-negative (E. coli) and gram-positive (Salmonella and S. aureus). Gonad extract can be a good source of antibacterial agents.
\end{abstract}

\section{Introduction}

Sea urchin (Phylum Echinodermata, Class Echinoid) is a commodity traded in many countries, has a hard shell and the inside is five symmetrical. Certain types of Sea urchin have shells coated with black pigments. In addition to having a hard shell, $95 \%$ of the body parts of the pig are dominated by very fragile and toxic thorns. These thorns are used to move, protect themselves, and stimulate food, and for certain types contain toxins. The toxins produced by sea urchin can be utilized in the field of treatment that is potentially used as antibiotics new types to be developed in the pharmaceutical field because it contains bioactive compounds (Abubakar et $a l ., 2012$ ). The sea urchin has an innate immune system that is potentially an effective new antimicrobial. The need to find new antimicrobial material is increasing, because the growth and development of bacteria are currently able to be resistant to antibiotics, as well as the growing conventional antibiotics (Li et al., 2008). The increasing number of studies showing that bacteria can be resistant to conventional antibiotics has encouraged researchers to find new antimicrobial agents derived from natural substances (vegetable and animal). As invertebrates, sea urchin does not have an adaptive immune system as it belongs to the type of vertebrates (Rast et al., 2006; Smith et al., 2006). The ability to defend itself in the form of resistance to infection attacks from attacking microorganisms, phagocytosis ability (the role of white blood cells in the immune system) and encapsulation (Hildemann and Dix, 1972; Coffaro and Hinegardner, 1977; Ito et al., 1992; Silva, 2000). In recent decades, there has been an increase in marine field research (crustaceans, molluscs and echinoderms) with an object of secondary metabolite content and type of antimicrobial (Haug et al., 2002; Casas et al., 2011).

Research from Rinehart et al. (1981), Bryan et al. (1997), Haug et al. (2002) and Li et al. (2008), exposing antimicrobial activity in several species of echinoderms acquired from the Caribbean, Mexico, the Gulf of California, and the Norwegian coast. Studied Prokof'eva et al. (2003) obtained antimicrobial compounds such as steroidal glycoside, polyhydroxylated sterols (Zhou et 
al., 2014), naphthoquinone pigments (Amarowicz et al., 2012; Powell et al., 2014; Yoon et al., 2019), lysozymes (Cong et al., 2009), and antimicrobial peptides (Li et al., 2010) are in isolation from animal echinoderms. This research suggests that marine animals are potentially developed as potential sources as antibiotics in the pharmaceutical field. Other studies reported by (Haug et al., 2002), showed that antibacterial activity was found on different parts of green sea urchin using test bacteria Vibrio anguillarum serotype O2 (FT 1801), Escherichia coli (ATCC 15922) and Staphylococcus aureus (ATCC 9144) and Corynebacterium glutamicum (ATCC 13032). These results indicate that the phylum echinoderms one of them has potential as a natural antimicrobial (Uma and Parvathavarthini, 2010).

Foodborne microbial pathogens contaminating food have been a human concern for a long time. Human attempts to control microbial food contamination have thus also been a long journey; from old-school methods such as heat-processing and cold-processing to chemically induced antimicrobial agents. Consumer awareness, concerns about the potential risk of synthetic food additives to human health, as well as urgent concerns about the freshness of food, have led to renewed interest in exploring more organic and natural methods of food preservation ( $\mathrm{Si}$ et al., 2006; Rahardiyan, 2019). Research antimicrobial activity on sea urchin has been carried out, from all organs and tissues (gonads and shell). But testing antimicrobial activity by using extracts derived from ultrasonicassisted extraction (UAE) has not been conducted by other researchers. Potential sea urchin as an antibacterial need to be developed because it can be utilized as a medicinal ingredient in the field of pharmacy. The study is aimed to obtain the swine fleece extract using the ultrasonic-assisted extraction methods, determining antibacterial activity using disc diffusion methods, and bioactive antibacterial components using gas chromatography-mass spectrometry (GC-MS). The research is focused on screening and comparing antimicrobial and hemolytic activity in various organs/ tissues of sea urchin Diadema setosum (Echinoidea) obtained from Cape of Palette, Bone Regency, South Sulawesi.

\section{Materials and methods}

\subsection{Materials}

Sea urchin (Diadema setosum) collected from the Cape of Palette, Bone Regency, South Sulawesi, Indonesia. The gonads separated from the sea urchin shell (Figure 1), then washed to remove other components and taken to the laboratory by carrying in the coolbox and stored in the freezer $\left(-10^{\circ} \mathrm{C}\right)$ until the gonads and shell sea urchin processed in Food Science and Instrumental Analysis Laboratory, Chemical Engineering Department, Politeknik Negeri Ujung Pandang, Indonesia.
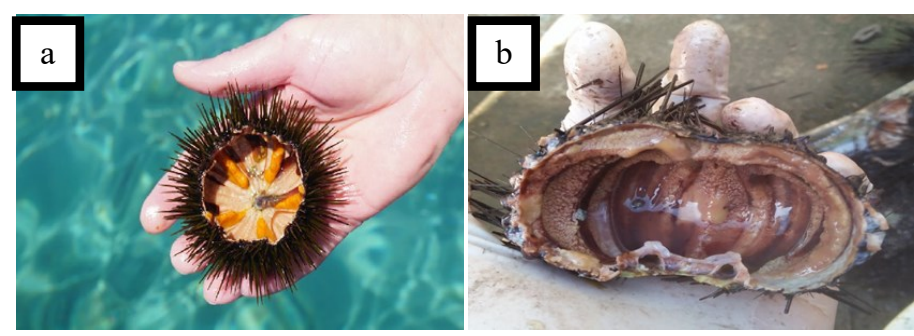

Figure 1. Sea urchin Diadema setosum: a) gonad and b) shell

All chemicals were of analytical grade, ethyl acetate (CAS: 141-78-6), methanol (CAS: 67-56-1), aquadestilata (CAS: 7732-18-5), nutrient agar (CAS:105450), plate count agar (CAS: 105463), EMB agar (CAS: 101347), sodium chloride (CAS: 7647-14-5), $\mathrm{pH}$ paper, disc antibiotic blank (Whatman No.1 and No.5), dimethyl sulfoxide (CAS: 67-68-5) supplied by Merck Millipore (Burlington, Massachusetts, United States), Tetracycline hydrochloride (CAS: 64-75-5) supplied by Sigma Aldrich (St. Louis, Missouri, United States), beef and fish meat from carrefour, culture strains Salmonella, Escherichia coli, and Staphylococcus aureus. Tools used are water bath (Memmert WNB 7 Basic control) Hettich Zentrifugen EBA-20, rotary evaporator Buchi, Hitachi centrifuge brands, Ultrasonic Assisted Extraction instrument (Elmasonic P30), and Shimadzu GC-MS 2010 brand Gas ChromatographyMass Spectrometry plus.

\subsection{Preparation of extracts}

Samples (200 g) gonads and shell of sea urchin were homogenized and extracted using Ultrasonic assisted extraction method with a ratio of Volume 1:1.5 (w/v) methanol or ethyl acetate for 30 and 60 mins, then in the rotary evaporator at $39^{\circ} \mathrm{C}$ temperature, followed by a shaker at a temperature of $10^{\circ} \mathrm{C}$ for $24 \mathrm{hrs}$. The Supernatant is produced for each sample, then in centrifugation for 10 mins and stored at a temperature of $10^{\circ} \mathrm{C}$, for use in testing the antibacterial disc diffusion method.

\subsection{Gas chromatography-mass spectrometry (GC-MS)}

Gonads and Shell extract of sea urchin were analyzed using GC-MS using capillary column DB-5 (30 $\mu \mathrm{m}, 0.25 \mu \mathrm{mm}, 0.25 \mu \mathrm{m}$ film) and Flame Ionization Detector (FID) operated in EI mode at $70 \mathrm{eV}$. The injectors and detector temperature are set at 220 and $250^{\circ} \mathrm{C}$. About $1 \mathrm{~mL}$ extract of sea urchin sample was dissolved with $3 \mathrm{~mL}$ methanol $96 \%$, then injected and analyzed at $60^{\circ} \mathrm{C}$ for $2 \mathrm{mins}$ and then increased $3^{\circ} \mathrm{C} / \mathrm{min}$ to $300^{\circ} \mathrm{C}$, with Helium $(\mathrm{He})$ is used as carrier gas $(1 \mathrm{~mL} /$ 
min). The relative number of each component is expressed as a percentage peak area relative to the total peak area. Qualitative identification of different constituents is done by comparison of the relative retention time and the mass spectrum with authentic reference compounds, or by the retention index (RIS) and the mass spectrum.

\subsection{Test microorganisms and culture media}

Test microorganisms Escherichia coli (gramnegative), Salmonella (gram-positive), and Staphylococcus aureus (gram-positive), used in these studies were obtained from the Microbiology Laboratory, Department of Biology, State University of Makassar. The isolated bacteria will grow at a temperature of $32^{\circ} \mathrm{C}$ in nutrient broth (DIFCO Laboratories, Detroit, USA) in accordance with standard procedures (Keagle and Gersen, 2005).

\subsection{Antimicrobial assay}

Disc antibiotic blank (Whatman No. 1) cut to size and sterilized with other equipment using autoclaved at $121^{\circ} \mathrm{C}$ for 15 mins. Growth media microorganisms are 5 $\mathrm{g}$ nutrient agar (NA), dissolved $250 \mathrm{~mL}$ of aquadest in the Erlenmeyer $500 \mathrm{~mL}$, then heated to homogeneous. The chloride sodium solvent is obtained by $0.9 \mathrm{~g} \mathrm{NaCl}$, then dissolved in a $100 \mathrm{~mL}$ volumetric flask, and inserted into the reaction tube $9 \mathrm{~mL}$. Mc Farland solvent obtained, by mixing a solution of barium chloride $\left(\mathrm{BaCl}_{2}\right) 1.175 \%$ and a solution of sulphuric acid $\left(\mathrm{H}_{2} \mathrm{SO}_{4}\right)$ $1 \%$, so that the solvent obtained Mc Farland $0.5 \%$ to be used as standard turbidity. Media nutrient agar, chloride sodium solvent and Mc Farland solvent in sterilization using autoclaved at temperature $121^{\circ} \mathrm{C}$ for $15 \mathrm{~min}$.

Bacteria Salmonella sp., Escherichia coli, and Staphylococcus aureus, as much as $20 \mathrm{~mL}$ of sterile nutrient agar was poured in Petri dishes, allowed to set at $37^{\circ} \mathrm{C}$ and then inoculate uniformLy with $0.1 \mathrm{~mL}$ of a 24 hrs broth culture of test bacteria (Abubakar et al., 2012; Syahirah and Rabeta, 2019). The gonad and shell extract sea urchin $0.25 \mathrm{~g}$ was dissolved in $1 \mathrm{~mL}$ aqueous dimethylsulfoxide (DMSO) with Tween $80(0.5 \% \mathrm{v} / \mathrm{v}$ for easy diffusion) and sterilized by filtration through a 0.45 $\mu \mathrm{m}$ membrane filter. Under the aseptic condition, each sterile disc (Whatman no. 5, $6 \mathrm{~mm}$ dia) was then dipped in $20 \mu \mathrm{L}$ of the gonad and shell of extracts sea urchin and carefully placed on the agar plate using flame sterilized forceps, ensuring the discs were at least $2 \mathrm{~cm}$ separate from one another. After 30 mins, plates were inverted and incubated at $37^{\circ} \mathrm{C}$ for $24 \mathrm{hrs}$, followed by measuring the inhibitory zone for each sample and the type of bacteria in $\mathrm{mm}$. The experiment was carried out in duplicate and the averages diameter of zone of inhibition was recorded. Negative controls use a 10\% DMSO solvent, and one paper disc is given a tetracycline of $\mathrm{HCl}$ as a positive control, antibacterial activity was classified as highly active $(>10 \mathrm{~mm})$, mild active $(7-10 \mathrm{~mm})$ and slightly active $(6-7 \mathrm{~mm})$ and less than $6 \mathrm{~mm}$ was taken as inactive (Chandra et al., 2011).

\subsection{Application in beef and fish meat}

Extracts that have the best inhibitory zone against bacteria E. coli, Salmonella sp and S. aureus are applied to beef and fish meat. $0.75 \mathrm{~g}$ of samples were dissolved in $3 \mathrm{~mL}$ aqueous dimethylsulfoxide (DMSO), beef and fish were cut in rectangular form $4 \mathrm{~g}$, soaked into extract solution, meat was stored on $48 \mathrm{hrs}$. The sample control is meat without the addition of extracts, as long as storage is observed physical parameters colour, aroma, texture and slime. After $48 \mathrm{hrs}$ of storage, $1 \mathrm{~mL}$ each of sterile plate count agar (PCA) and eosin methylene blue agar (EMBA) was poured in Petri dishes, meat dissolved in the $\mathrm{NaCl}$ and inoculate uniformLy with $0.1 \mathrm{~mL}$ (dilution $10^{-1}, 10^{-2}, 10^{-3}$ and $10^{-4}$ ) at $37^{\circ} \mathrm{C}$ for $24 \mathrm{hrs}$ of test bacteria.

\section{Results and discussion}

\subsection{GC-MS analysis}

The presence of antibacterial components in the methanol and ethyl acetate extract of gonad and shell of sea urchin was characterized by GC-MS analysis (Table $1)$.

Thirteen constituents were predominantly found in the gonad and shell extract of sea urchin (Table 1). Six of these were from the methanol extract of gonad sea urchin. They include n-hexadecanoic acid (39.66\%), Pentadecanoic Acid (1.73\%), 9-Octadecenoic acid (Z) -, methyl ester (23.1\%), 9-Hexadecenoic acid, methyl ester, (Z)- (3.74\%), Tetradecanoic acid (21.01\%), oleic acid $(0.97 \%)$. While the remaining eight-i.e., Cholest-5-EN3-OL (3. Beta.) (44.19\%), n-Hexadecanoic acid (19.44\%), Ergosta-5,22-dien-3-ol, (3.beta.,22E) (6.32\%), Pentadecanoic Acid (1.06\%), 1,2-Benzenedicarboxylic Acid (0.10\%), 9-Octadecenoic acid (Z) -, methyl ester (4.84\%), Arachidonic acid (3.85\%) and 9-Hexadecenoic acid, methyl ester, $(Z)-(2.9 \%)$ were from the methanol extract of shell sea urchin (Table 1). Most of these constituents have been found to show interesting biological activity against certain illnesses and/or pathogens. For instance, the antioxidant, antiinflammatory, antibacterial, hypocholesterolemic activities reported for n-hexadecanoic acid, 9Octadecenoic acid (Z) -, methyl ester and Tetradecanoic acid, with the dominant amounts of the three components. 
Table 1. Antimicrobial composition of gonad and shell extract of sea urchin

\begin{tabular}{|c|c|c|c|c|c|}
\hline \multirow[b]{2}{*}{ Antibacterial Compound } & \multirow{2}{*}{$\begin{array}{l}\text { Molecular } \\
\text { formula }\end{array}$} & \multicolumn{2}{|c|}{ Peak area $(\%)$} & \multicolumn{2}{|c|}{ Peak area $(\%)$} \\
\hline & & $\begin{array}{l}\text { Methanol extract } \\
\text { of gonad }\end{array}$ & $\begin{array}{l}\text { Methanol extract } \\
\text { of shell }\end{array}$ & $\begin{array}{c}\text { Ethyl acetate } \\
\text { extract of gonad }\end{array}$ & $\begin{array}{l}\text { Ethyl acetate } \\
\text { extract of shell }\end{array}$ \\
\hline Cholest-5-EN-3-OL (3. Beta.)/ & $\mathrm{C}_{27} \mathrm{H}_{46} \mathrm{O}$ & - & 44.2 & 9.2 & 51.6 \\
\hline n-Hexadecanoic acid (Palmitic acid) & $\mathrm{C}_{16} \mathrm{H}_{32} \mathrm{O}_{2}$ & 39.7 & 19.4 & 8.4 & 2.7 \\
\hline $\begin{array}{l}\text { Ergosta-5,22-dien-3-ol, } \\
\text { (3.beta.,22E) }\end{array}$ & $\mathrm{C}_{28} \mathrm{H}_{46} \mathrm{O}$ & - & 6.3 & - & 10.7 \\
\hline Pentadecanoic Acid & $\mathrm{C}_{15} \mathrm{H}_{30} \mathrm{O}_{2}$ & 1.7 & 1.1 & 0.3 & - \\
\hline $\begin{array}{l}\text { 1,2-Benzenedicarboxylic Acid } \\
\text { (Phthalic Acid) }\end{array}$ & $\mathrm{C}_{24} \mathrm{H}_{38} \mathrm{O}_{4}$ & - & 0.1 & 8.1 & 0.6 \\
\hline 9-Octadecenoic acid (Z) -, methyl & $\mathrm{C}_{19} \mathrm{H}_{36} \mathrm{O}_{2}$ & 23.1 & 4.8 & 1.2 & 0.4 \\
\hline Arachidonic acid & $\mathrm{C}_{20} \mathrm{H}_{32} \mathrm{O}_{2}$ & - & 3.9 & - & - \\
\hline 9-Hexadecenoic acid, methyl ester, & $\mathrm{C}_{17} \mathrm{H}_{32} \mathrm{O}_{2}$ & 3.7 & 2.4 & 1.1 & 0.6 \\
\hline Tetradecanoic acid (Myristic acid) & $\mathrm{C}_{14} \mathrm{H}_{28} \mathrm{O}_{2}$ & 21.01 & - & 4.34 & 1.11 \\
\hline Oleic acid & $\mathrm{C}_{18} \mathrm{H}_{34} \mathrm{O}_{2}$ & 0.97 & - & - & - \\
\hline Pentacosane & $\mathrm{C}_{25} \mathrm{H}_{52}$ & - & - & 35.61 & 15.45 \\
\hline Tetratetracontane & $\mathrm{C}_{4}{ }_{4} \mathrm{H}_{90}$ & - & - & 6.88 & 6.53 \\
\hline Stigmast-5-EN-3-OL, (3.Beta.,24S)- & $\mathrm{C}_{29} \mathrm{H}_{50} \mathrm{O}$ & - & - & 5.9 & - \\
\hline
\end{tabular}

There were ten antimicrobial compounds that were present in considerable amounts $(80.93 \%)$ found in ethyl acetate extract of gonad sea urchin, and another nine antimicrobial compounds comprised $89.59 \%$ (Table 1). A component 9-Hexadecenoic acid, methyl ester, Pentacosane, -Octadecenoic acid (Z) -, methyl ester and Cholest-5-EN-3-OL (3. Beta.) have been reported to have antimicrobial activity. The presence of these compounds makes gonad and shell extract of sea urchin leaves a source of bioactive compound. Other minor compounds like n-Hexadecanoic acid have antibacterial properties, whereas Tetradecanoic acid, Tetratetracontane and Stigmast-5-EN-3-OL,(3.Beta.,24S) has antimicrobial activity.

\subsection{Antibacterial Activity}

Disc diffusion method was followed to determine the antimicrobial activity. Antimicrobial activities of gonad and shell of sea urchin (Diadema setosum) extracts were evaluated against three bacterial (two gram-positive, one gram-negative) strains with two replicates being tested in the agar plate. The ethyl acetate solutions of the extracts were found to have potent antimicrobial activity against all the gram-positive and gram-negative bacteria tested by disc diffusion assay as shown in Table 2 .

\subsubsection{Antibacterial activity against Escherichia coli}

Methanol and ethyl acetate extract of sea urchin for extraction 30 and 60 mins, exhibited a broad-spectrum antimicrobial activity with a minimum zone diameter of $6.5 \mathrm{~mm}$ for methanol extract of a shell with 30 mins extraction and ethyl acetate extract of gonad with 30 mins extraction a maximum zone diameter of $7.4 \mathrm{~mm}$ against on E. coli. Ethyl acetate and methanol extract showed slightly active activity against $E$. coli with a diameter of inhibitory zone $6-7 \mathrm{~mm}$ (Table 2 and Figure 2). The diameter of the inhibition zone ( $\mathrm{mm})$ was measured and the activity index was also calculated.
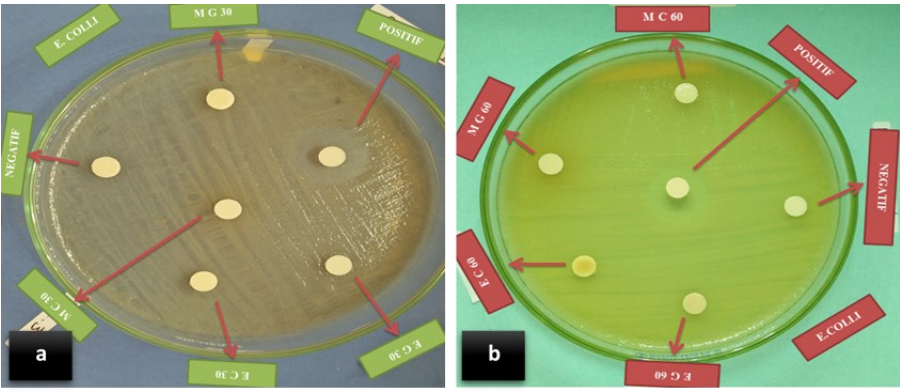

Figure 2. Antibacterial activity of methanol and ethyl acetate extract (gonad and shell) against Escherichia coli: a) 30 mins extraction; b) 60 mins extraction. Sample EG30 (ethyl acetate extract of gonad, 30 mins); EC30 (ethyl acetate extract of shell, 30 mins); MG30 (methanol extract of gonad, 30 mins); MC30 (methanol extract of shell, 30 mins); Sample EG60 (ethyl acetate extract of gonad, 60 mins); EC60 (ethyl acetate extract of shell, 60 mins); MG60 (methanol extract of gonad, 60 mins); MC60 (methanol extract of shell, 60 mins).

\subsubsection{Antibacterial activity against Salmonella}

Methanol and ethyl acetate extract of sea urchin for extraction 30 and 60 mins, and two replicates of the samples being tested in the agar plate. Exhibited a broadspectrum antimicrobial activity with a minimum zone diameter of $8.8 \mathrm{~mm}$ for methanol extract of a shell with 30 mins extraction and ethyl acetate extract of gonad with 30 mins extraction a maximum zone diameter of $12.6 \mathrm{~mm}$ against on Salmonella. These result also showed ethyl acetate and methanol extracts as highly active activity against $E$. coli with a diameter of 
Table 2. Effect of gonad and shell extract of sea urchin against different pathogens

\begin{tabular}{|c|c|c|c|c|c|}
\hline \multirow{2}{*}{ Samples } & \multirow{2}{*}{$\begin{array}{l}\text { Extraction time } \\
(\mathrm{min})\end{array}$} & \multirow{2}{*}{ Volume } & \multicolumn{3}{|c|}{ Zone of inhibition (mm) } \\
\hline & & & E. coli & Salmonella & S. aureus \\
\hline \multirow{2}{*}{ Methanol extract of gonad sea urchin } & 30 & \multirow{2}{*}{$20 \mu \mathrm{L}$} & 6.7 & 9.6 & 8.5 \\
\hline & 60 & & 6.9 & 10.5 & 11.2 \\
\hline \multirow{2}{*}{ Methanol extract of shell sea urchin } & 30 & \multirow{2}{*}{$20 \mu \mathrm{L}$} & 6.5 & 8.8 & 7.6 \\
\hline & 60 & & 6.8 & 9.5 & 11 \\
\hline \multirow{2}{*}{$\begin{array}{l}\text { Ethyl acetate extract of gonad sea } \\
\text { urchin }\end{array}$} & 30 & \multirow{2}{*}{$20 \mu \mathrm{L}$} & 7.4 & 12.6 & 11.8 \\
\hline & 60 & & 7.2 & 12.3 & 12.1 \\
\hline \multirow{2}{*}{$\begin{array}{l}\text { Ethyl acetate extract of shell sea } \\
\text { urchin }\end{array}$} & 30 & \multirow{2}{*}{$20 \mu \mathrm{L}$} & 6.8 & 11.5 & 10.9 \\
\hline & 60 & & 6.9 & 10.3 & 10.6 \\
\hline Control positive & 30 & \multirow{2}{*}{$20 \mu \mathrm{L}$} & 17.3 & 35.7 & 32.5 \\
\hline Contol negative & 30 & & 0 & 0 & 0 \\
\hline Control positive & 60 & \multirow{2}{*}{$20 \mu \mathrm{L}$} & 17.2 & 33 & 33 \\
\hline Control negative & 60 & & 0 & 0 & 0 \\
\hline
\end{tabular}

inhibitory zone greater than $10 \mathrm{~mm}$ (Table 2 and Figure 3).
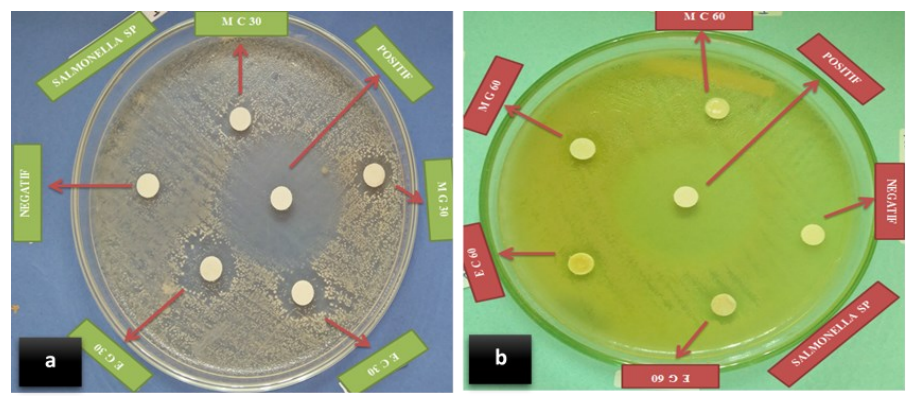

Figure 3. Antibacterial activity of methanol and ethyl acetate extract (gonad and shell) against Salmonella: a) 30 mins extraction; and b) 60 mins extraction.

\subsubsection{Antibacterial activity against Staphylococcus aureus}

Methanol and ethyl acetate extract of sea urchin for extraction 30 and 60 mins, exhibited a broad-spectrum antimicrobial activity with a minimum zone diameter of $7,6 \mathrm{~mm}$ for methanol extract of a shell with 30 mins extraction and ethyl acetate extract of gonad with 60 mins extraction a maximum zone diameter of $12,1 \mathrm{~mm}$ against on $S$. aureus. These result also showed ethyl acetate and methanol extracts as highly active activity against $S$. aureus with a diameter of inhibitory zone greater than $10 \mathrm{~mm}$ (Table 2 and Figure 4).

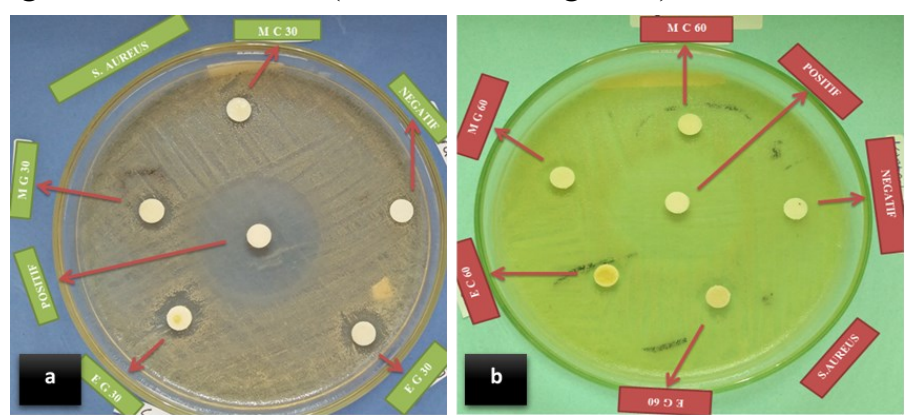

Figure 4. Antibacterial activity of methanol and ethyl acetate extract (gonad and shell) against Staphylococcus aureus: a) 30 mins extraction; and b) 60 mins extraction.

The preliminary antimicrobial assay of the extracts showed different responses to the test organisms with the best activity observed for both methanol and ethyl acetate extracts of gonad and shell sea urchin against bacteria gram-positive (Salmonella and S. aureus). The gonad and shell sea urchin extracts were observed to show poor activity against the test pathogens bacteria gram-negative (E. coli).

\subsection{Application in beef and fish meat}

The results showed, that ethyl acetate extract of gonads with 30 mins extraction is the best condition to produce antibacterial compounds found in the sea urchin because it can highly activity inhibitory zone against bacteria E. coli, Salmonella and S. aureus. The result of this extract will be applied to fresh food i.e. beef and fish meat (Table 3, Figures 5 and 6).
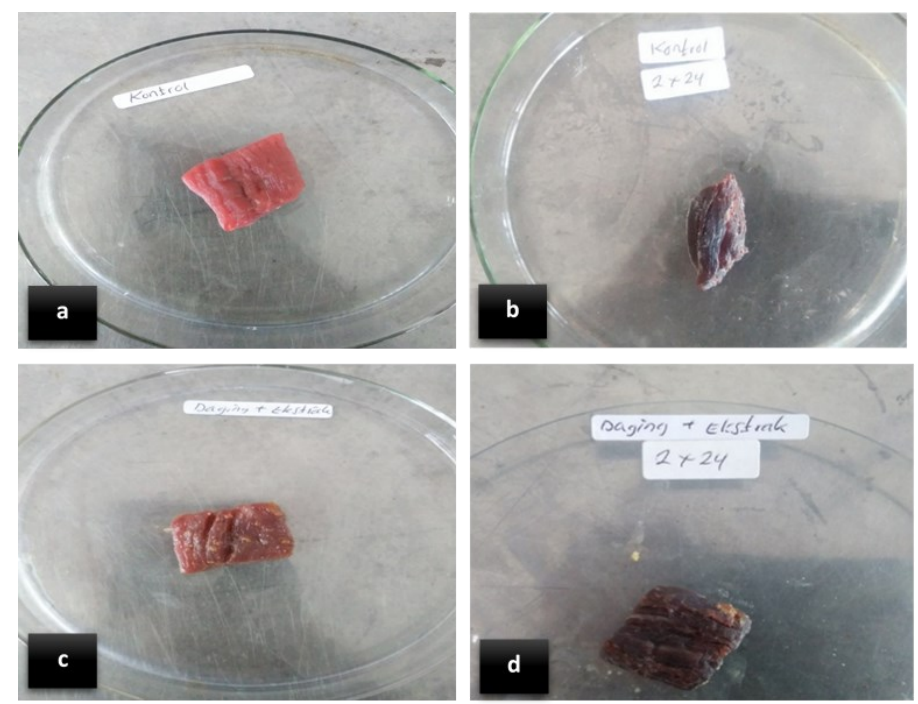

Figure 5. Application ethyl acetate extract of the gonad in beef meat: a) sample of beef control at $0 \mathrm{hrs}$; b) sample of beef control after $48 \mathrm{hrs}$; c) sample of beef with ethyl acetate extract of gonad at $0 \mathrm{hrs}$; and d) sample of beef with ethyl acetate extract of gonad after $48 \mathrm{hrs}$

The amount of bacteria that grows in beef meats that are not soaked in extracts (sample control) is $2.5 \times 10^{5}$ $\mathrm{CFU} / \mathrm{g}$. Beef meat that is not added ethyl acetate extract of gonads sea urchin has suffered damage due to bacterial growth. In samples of beef meat given ethyl 
Table 3. Amount of microbial after 48 hrs of storage using Total Plate Count Test (TPC)

\begin{tabular}{lcccccc}
\hline \multicolumn{1}{c}{ Sample } & \multicolumn{3}{c}{ Dilution $(\mathrm{CFU} / \mathrm{g})$} & \multirow{2}{*}{ TPC (CFU/g) } \\
\cline { 2 - 5 } & $10^{-1}$ & $10^{-2}$ & $10^{-3}$ & $10-^{4}$ & $2.5 \times 10^{5}$ \\
\hline Control beef meat & TNTC & TNTC & 252 & 18 & - \\
Sample ethyl acetate extract of gonad in beef meat & 0 & 0 & 0 & 0 & $1.4 \times 10^{5}$ \\
Control fish meat & TNTC & TNTC & 145 & 28 & $8 \times 10^{1}$ \\
Sample ethyl acetate extract of gonad in beef meat & 8 & - & - & - &
\end{tabular}

TNTC $=$ To Numerous To Count
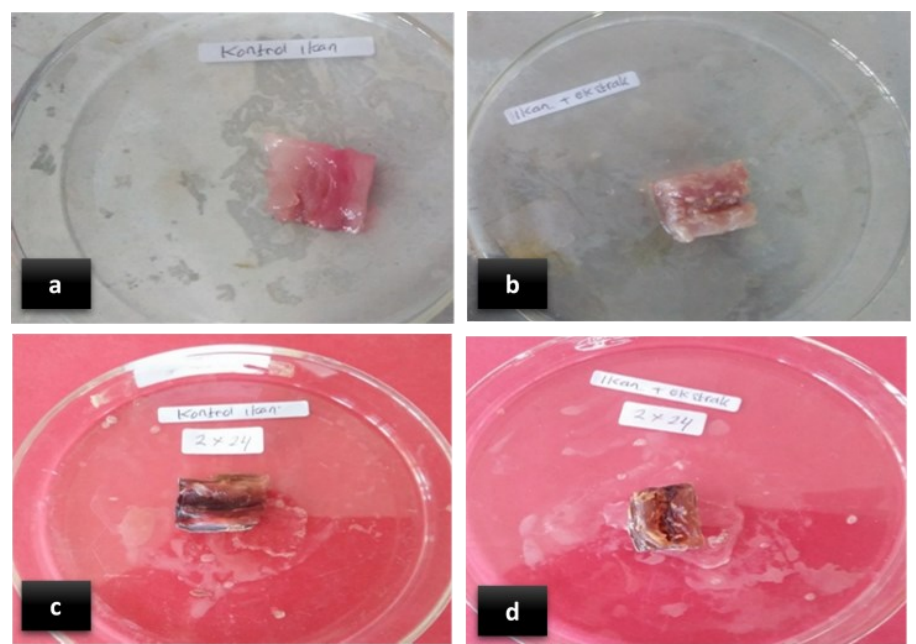

Figure 6. Application ethyl acetate extract of the gonad in fish meat: a) sample of fish control at $0 \mathrm{hrs}$; b) sample of fish control after $48 \mathrm{hrs}$; c) sample of fish with ethyl acetate extract of gonad at $0 \mathrm{hrs}$; and d) sample of fish with ethyl acetate extract of gonad after $48 \mathrm{hrs}$

acetate extract of gonads, sea urchin is not damaged and overgrown by pathogenic bacteria, due to the presence of antibacterial compounds that inhibit the growth of bacteria during storage of $48 \mathrm{hrs}$. The same thing on a sample of fish meat (sample control), overgrown by a microbial of $1.4 \times 10^{5} \mathrm{CFU} / \mathrm{g}$, while fish meat is given ethyl acetate extract of gonads sea urchin only overgrown microbes amounting to $8 \times 10^{1} \mathrm{CFU} / \mathrm{g}$ during

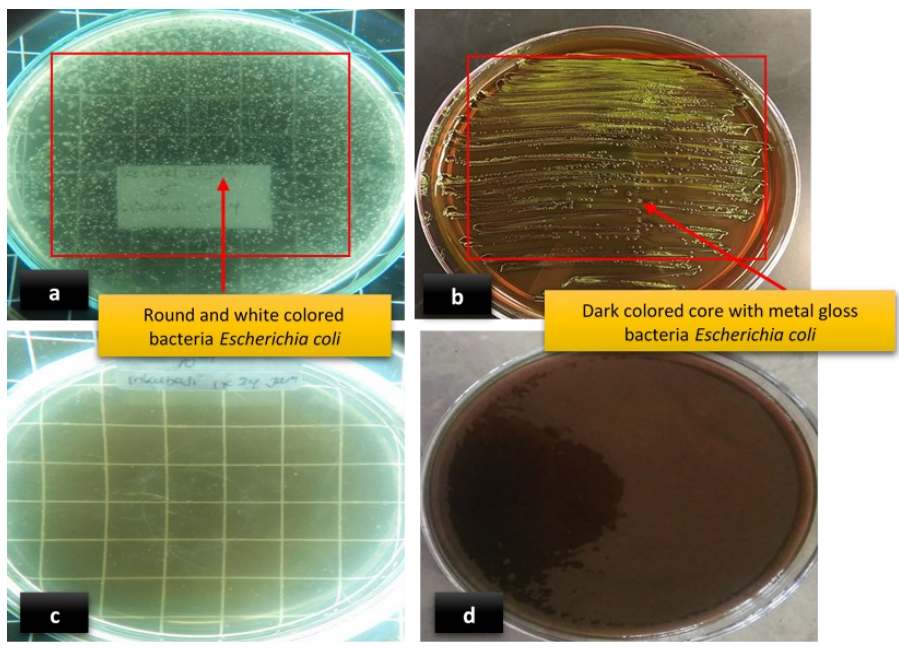

Figure 7. Observation of samples after $48 \mathrm{hrs}$ of storage: a) sample of beef control in the media plate count agar (dilution $\left.10^{-1}\right)$; b) sample of beef control in the media eosin methylene blue agar; c) sample of beef with ethyl acetate extract of the gonad in the media plate count agar (dilution $10^{-1}$ ); and $\mathrm{d}$ ) sample of beef with ethyl acetate extract of the gonad in the media eosin methylene blue agar.

eISSN: 2550-2166 storage $48 \mathrm{hrs}$. Fish meat is more rapidly damaged than beef because the protein contains very few tendons or binders so that easy to digest the body and easier to decompose (rot). High Protein (about 15 to $20 \%$ of other types of meat), as well as meat almost without tendons, makes fish meat a good medium for the growth of the microorganisms (Zhang et al., 2016). Damage by pathogenic microbes can be seen clearly when both samples in isolation on the media plate count agar and eosin methylene blue agar (Figures 7 and 8).

The results showed that Eosin Methylene Blue Agar (EMBA) is a medium used to determine the presence or absence of coliform bacteria in a sample. The medium of EMBA for this has the privilege of containing lactose and serves to distinguish microbes that fermenting lactose such as $S$. aureus, Pseudomonas aerugenosa, and Salmonella. Microbes that ferment lactose produce colonies with dark nuclei with metal gloss. Other microbes that can grow their colonies are colourless. The functions of eosin and methylene blue help sharpen the colour difference. Nevertheless, if this medium is used in the early stages, other germs can also grow mainly Pseudomonas aerugenosa, and Salmonella sp., so this

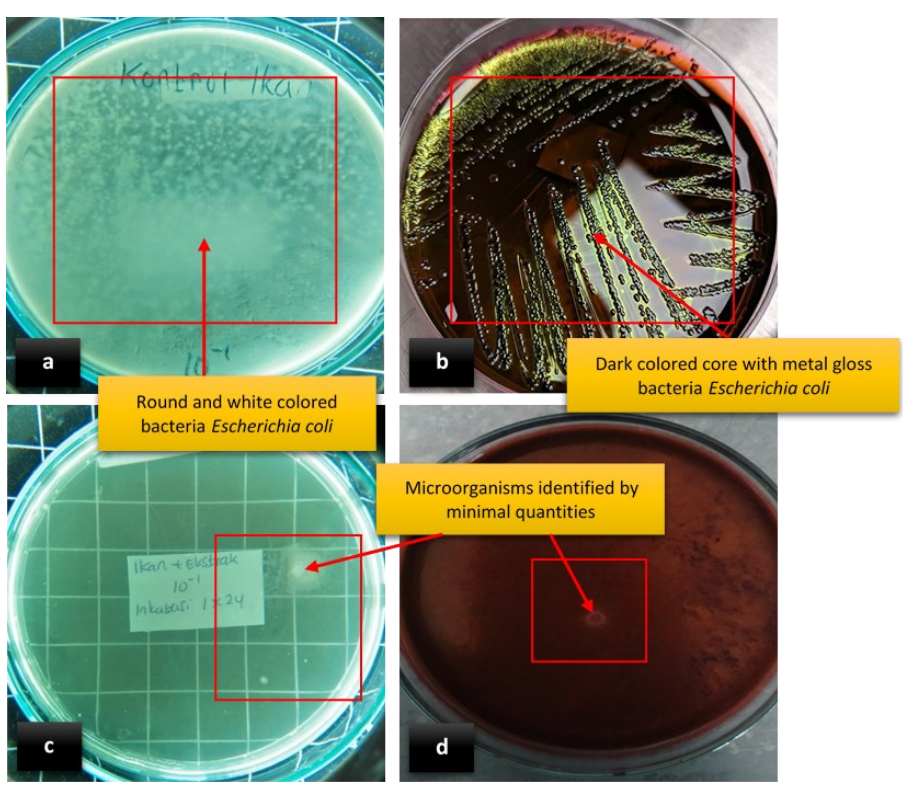

Figure 8 . Observation of samples after $48 \mathrm{hrs}$ of storage: a) sample of fish control in the media plate count agar (dilution $\left.10^{-1}\right)$; b) sample of fish control in the media eosin methylene blue agar; c) sample of fish with ethyl acetate extract of the gonad in the media plate count agar (dilution $10^{-1}$ ); and d) sample of fish with ethyl acetate extract of the gonad in the media eosin methylene blue agar 
can lead to doubts. This media is very good to confirm that the contaminants are Escherichia coli. This solid shaped medium is useful for keeping cells from moving places so that it will easily be counted and separated by type when growing into a colony. Solid media also reveals the diffusion of bacterial metabolites to facilitate the testing of a metabolite result.

\section{Conclusion}

Gonad and shell sea urchin are the sources of secondary metabolites; n-hexadecanoic acid, Pentadecanoic acid, 9-Octadecenoic acid (Z) -, methyl ester, 9-Hexadecenoic acid, methyl ester, (Z)-, Tetradecanoic acid, oleic acid, Cholest-5-EN-3-OL (3. Beta.) (44.19\%), Ergosta-5,22-dien-3-ol, (3.beta.,22E), 1,2-Benzenedicarboxylic Acid $(0.10 \%)$, Pentacosane, Tetratetracontane, and Stigmast-5-EN-3-OL, (3.Beta.,24S)-/ gamma sitosterol, that contributes to the antioxidant and antibacterial properties. Ethyl acetate extracts give the highest number of those antibacterial components for both gonad and shell samples. S. aureus and Salmonella (gram-positive bacteria) are more sensitive to gonad and shell sea urchin ethyl acetate extract because it has an inhibitory zone diameter greater than $10 \mathrm{~mm}$, and not sensitive to E. coli (gram-negative bacteria), with inhibitory zone diameter 6-7 $\mathrm{mm}$. However, further studies on the specific antimicrobial compound activities need to be tested and, possibly, a double or triple combination of the gonad and shell extracts could enhance each of their potencies.

\section{References}

Abubakar, L., Mwangi, C., Uku, J. and Ndirangu, S. (2012). Antimicrobial activity of various extracts of the sea urchin Tripneustes gratilla (Echinoidea). African Journal of Pharmacology and Therapeutics, 1(1), 19-23.

Amarowicz, R., Synowiecki, J. and Shahidi, F. (2012). Chemical composition of shells from red (Strongylocentrotus franciscanus) and green (Strongylocentrotus droebachiensis) sea urchin. Food Chemistry, 133(3), 822-826. https:// doi.org/10.1016/j.foodchem.2012.01.099

Bryan, P.J., McClintock, J.B. and Hopkins, T.S. (1997). Structural and chemical defenses of echinoderms from the northern Gulf of Mexico. Journal of Experimental Marine Biology and Ecology, 210(2), 173-186. https://doi.org/10.1016/S0022-0981(96) 02677-9

Casas, S.M., Comesaña, P., Cao, A. and Villalba, A. (2011). Comparison of antibacterial activity in the hemolymph of marine bivalves from Galicia (NW
Spain). Journal of Invertebrate Pathology, 106(2), 343-345. https://doi.org/10.1016/j.jip.2010.11.007

Chandra, R., Dwivedi, V., Shivam, K. and Jha, A.K. (2011). Detection of antimicrobial activity of Oscimum sanctum (Tulsi) and trigonella foenum graecum (Methi) against some selected bacterial and fungal strains. Research Journal of Pharmaceutical, Biological and Chemical Sciences, 2(4), 809-813.

Coffaro, K. A. and Hinegardner, R. T. (1977). Immune response in the sea urchin Lytechinus pictus. Science, 197(4311), 1389-1390. https://doi.org/10.1126/ science. 331476

Cong, L., Yang, X., Wang, X., Tada, M., Lu, M., Liu, H. and Zhu, B. (2009). Characterization of an i-type lysozyme gene from the sea cucumber Stichopus japonicus, and enzymatic and nonenzymatic antimicrobial activities of its recombinant protein. Journal of Bioscience and Bioengineering, 107(6), 583-588.

https://doi.org/10.1016/ j.jbiosc.2009.01.016

Haug, T., Kjuul, A.K., Styrvold, O.B., Sandsdalen, E., Olsen, Ø.M. and Stensvåg, K. (2002). Antibacterial activity in Strongylocentrotus droebachiensis (Echinoidea), Cucumaria frondosa (Holothuroidea), and Asterias rubens (Asteroidea). Journal of Invertebrate Pathology, 81(2), 94-102. https:// doi.org/10.1016/S0022-2011(02)00153-2

Hildemann, W.H. and Dix, T.G. (1972). Transplantation reactions of tropical Australian echinoderms. Transplantation, 14(5), 624-633. https:// doi.org/10.1097/00007890-197211000-00015

Ito, T., Matsutani, T., Mori, K. and Nomura, T. (1992). Phagocytosis and hydrogen peroxide production by phagocytes of the sea urchin Strongylocentrotus nudus. Developmental and Comparative Immunology, 16(4), 287-294. https:// doi.org/10.1016/0145-305X(92)90003-U

Keagle, M.B. and Gersen, S L. (2005). Basic laboratory procedures. In Gersen, S.L. and Keagel, M.B. (Eds.) The Principles of Clinical Cytogenetics, p. 1-188. Totowa, New Jersey: Humana Press. https:// doi.org/10.1385/1-59259-833-1:063

Li, C., Haug, T. and Stensvåg, K. (2010). Antimicrobial peptides in echinoderms. Invertebrate Survival Journal, 7(1), 132-140.

Li, Chun, Haug, T., Styrvold, O.B., Jørgensen, T.O. and Stensvåg, K. (2008). Strongylocins, novel antimicrobial peptides from the green sea urchin, Strongylocentrotus droebachiensis. Developmental and Comparative Immunology, 32(12), 1430-1440. https://doi.org/10.1016/j.dci.2008.06.013

Powell, C., Hughes, A.D., Kelly, M.S., Conner, S. and 
McDougall, G.J. (2014). Extraction and identification of antioxidant polyhydroxynaphthoquinone pigments from the sea urchin, Psammechinus miliaris. LWT - Food Science and Technology, 59(1), 455-460. https:// doi.org/10.1016/j.lwt.2014.05.016

Prokof'eva, N.G., Chaikina, E.L., Kicha, A.A. and Ivanchina, N.V. (2003). Biological activities of steroid glycosides from starfish. Comparative Biochemistry and Physiology - B Biochemistry and Molecular Biology, 134(4), 695-701. https:// doi.org/10.1016/S1096-4959(03)00029-0

Rahardiyan, D. (2019). Antibacterial potential of catechin of tea (Camellia sinensis) and its applications. Food Research, 3(1), 1-6. https:// doi.org/10.26656/fr.2017.3(1).097

Rast, J.P., Smith, L. C., Loza-Coll, M., Hibino, T. and Litman, G.W. (2006). Genomic insights into the immune system of the sea urchin. Science, 314 (5801), 952-956. https://doi.org/10.1126/ science. 1134301

Rinehart, K.L., Shaw, P.D., Shield, L.S., Gloer, J.B., Harbour, G.C., Koker, M.E.S., Samain, D., Schwartz, R.E., Tymiak, A.A., Weller, D.L., Carter, G.T., Munro, M.H.G., Hughes, R.G., Renis, H.E., Swynenberg, E.B., Stringfellow, D.A., Vavra, J.J., Coats, J.H., Zurenko, G.E., Kuentzel, S.L., Li, L.H., Bakus, J.G., Brusca, R.C., Craft, L.L., Young, D.N. and Connor, J.L. (1981). Marine natural products as sources of antiviral, antimicrobial, and antineoplastic agents. Pure and Applied Chemistry, 53(4), 795817. https://doi.org/10.1351/pac198153040795

Si, W., Gong, J., Tsao, R., Kalab, M., Yang, R. and Yin, Y. (2006). Bioassay-guided purification and identification of antimicrobial components in Chinese green tea extract. Journal of Chromatography A, 1125(2), 204-210. https:// doi.org/10.1016/j.chroma.2006.05.061

Silva, J.R.M.C. (2000). The onset of phagocytosis and identity in the embryo of Lytechinus variegatus. Developmental and Comparative Immunology, 24 (8), 733-739. https://doi.org/10.1016/S0145-305X (00)00028-8

Smith, L.C., Rast, J.P., Brockton, V., Terwilliger, D.P., Nair, S.V., Buckley, K.M. and Majeske, A.J. (2006). The sea urchin immune system. Invertebrate Survival Journal, 3(1), 25-39.

Syahirah, J. and Rabeta, M.S. (2019). Antioxidant and antimicrobial activity of lemuni noodle. Food Research, 3(1), 7-13. https://doi.org/10.26656/ fr.2017.3(1).090

Uma, B. and Parvathavarthini, R. (2010). Antibacterial effect of hexane extract of sea Urchin, Temnopleurus alexandri (Bell,1884). International Journal of PharmTech Research, 2(3), 1677-1680.

Yoon, C.S., Kim, H.K., Mishchenko, N.P., Vasileva, E.A., Fedoreyev, S.A., Stonik, V.A. and Han, J. (2019). Spinochrome D attenuates doxorubicininduced cardiomyocyte death via improving glutathione metabolism and attenuating oxidative stress. Marine Drugs, 17(1), 1-20. https:// doi.org/10.3390/md17010002

Zhang, T., Xue, Y., Li, Z., Wang, Y., Yang, W. and Xue, C. (2016). Effects of ozone on the removal of geosmin and the physicochemical properties of fish meat from bighead carp (Hypophthalmichthys nobilis). Innovative Food Science and Emerging Technologies, 34, 16-23. https://doi.org/10.1016/ j.ifset.2016.01.001

Zhou, X., Sun, J., Ma, W., Fang, W., Chen, Z., Yang, B. and Liu, Y. (2014). Bioactivities of six sterols isolated from marine invertebrates. Pharmaceutical Biology, 52(2), 187-190. https:// doi.org/10.3109/13880209.2013.821664 